\title{
Assessment of Water Demand in Al-Anbar Province- Iraq
}

\author{
Ameen M. Noon ${ }^{1, *}$, Hany G. I. Ahmed ${ }^{2}$, Sadeq O. Sulaiman ${ }^{1}$ \\ ${ }^{1}$ Dams and Water Resources Engineering Department, College of Engineering, University of Anbar, Ramadi, Iraq \\ ${ }^{2}$ Department of Irrigation and Hydraulics, Faculty of Engineering, Al-Azhar University, Cairo, Egypt
}

Received February 16, 2021; Revised April 2, 2021; Accepted April 22, 2021

\section{Cite This Paper in the following Citation Styles}

(a): [1] Ameen M. Noon, Hany G. I. Ahmed, Sadeq O. Sulaiman , "Assessment of Water Demand in Al-Anbar ProvinceIraq," Environment and Ecology Research, Vol. 9, No.2, pp. 64 - 75, 2021. DOI: 10.13189/eer.2021.090203.

(b): Ameen M. Noon, Hany G. I. Ahmed, Sadeq O. Sulaiman (2021). Assessment of Water Demand in Al-Anbar Province- Iraq. Environment and Ecology Research, 9(2), 64 - 75. DOI: 10.13189/eer.2021.090203.

Copyright@2021 by authors, all rights reserved. Authors agree that this article remains permanently open access under the terms of the Creative Commons Attribution License 4.0 International License

\begin{abstract}
The water issue has posed a great challenge in the past twenty years in most Arab countries, including Iraq in particular, due to the establishment of many dams by Turkey, which led to a decrease in the annual rate of water resources and non-compliance with international law of trans-boundary water management. The west of Iraq is considered as an arid region and suffers scarcity of rain, which has led to severe drought and seriously affected water resources in terms of quality and quantity. In this study, a numerical model of water resources management for the Euphrates River is applied by using Water Evaluation And Planning (WEAP). Anbar Province is selected to apply this model, in order to assess past trends in water resources management and to simulate current demand scenarios which must be known for the decision-makers and water resources managers, namely the reference scenario and the water tax scenario. The results showed that the demand for water in the reference scenario (2040) will be 2819.35 million cubic meters per year while the corresponding demand in the other scenario will be 2639.54 million cubic meters per year, which amounts to 179.81 million cubic meters per year saving that can be exploited.
\end{abstract}

Keywords WEAP Model, Water Resources Management, Euphrates River, Sustainability, Water Supply, Water Demand

\section{Introduction}

Iraq has witnessed severe drought events while arid regions suffer from low precipitation range and high temperature which apply high stress on the existing water resources. The succession of droughts as a result of global climate changes, required a review of water uses through updating and developing institutional structures to accommodate the requirements and objectives of integrated water resources management and the use of modern technologies. [1]. In Iraq, whose surface water is originated from outside and thus the source countries that share with it (Turkey, Syria) control the water in the legalization of its water share continuously, as well as the excessive and irrational use of water for all purposes (domestic, agricultural, industrial), [2].located in the Middle East region which is characterized by its water shortage problem [3] where at least 12 countries have acute water scarcity problems with less than $500 \mathrm{~m}^{3}$ of renewable water resources per capita available [4]. The rainfall scarcity and high temperatures due to climate changes have led to a shortage of water in the whole region, and in recent years [5]. The country is suffering from shortage of water resources for the Euphrates and Tigris rivers and their tributaries due to the climate changes and the drought status of the Middle East, and because of the unfair water policy by Turkey and Iran countries [6] [7]. Additionally, the rivers suffer from water quality deterioration due to the discharge of wastewater [8]. The research problem is centered on the fact that Iraq in general and Anbar Province, in particular, are facing a real water 
problem represented by a decrease in the supply of water quantities in the Euphrates River.

The WEAP model was previously applied in assessing the future water demand of the Niger River for the cities of Niamey and Tillabéry. The results showed that there will be a deficit in 2030 for the high population growth scenario and the changing climate scenario of 33.7 million cubic meters that would be fortunately covered when a hydro-electric dam is built on the Niger River that will provide water for agriculture and drinking [9]. The WEAP model was also applied to explore water shortages at the watershed level in Beijing, China. The results showed that the total water demand was 2,417.57 million cubic meters, and the deficit was 560.24 million cubic meters in 2010 [10]. The WEAP model was also applied in assessing and planning water for future needs in Surat, India. In a comparison was made between the results made by Surat Municipal Corporation for the average water supply, the result was 840 million cubic meters in 2012 and 900 million cubic meters in 2013.The results obtained from the study indicate that the model can work well for assessing future water demand [11]. The WEAP model was also to water supply and demand in the Aral Sea region, which is located in the arid south-central regions of the former U.S.S.R. The results in the changing climate scenario, the Water Year scenario, showed that $11 \%$ of the water needed in the dry year is expected to be obtained and about $61 \%$ of water in normal years, where it can meet $44 \%$ of water requirements in normal years, and 30\% in dry and very dry years [12]. The WEAP program was also applied in simulating scenarios for managing wastewater resources across borders in Wadi Zomer, Palestine. The results showed that the amount of treated wastewater in the study area will reach 16 million cubic meters by 2035. The results also showed that one of the reasons for not using the treated wastewater is the lack of experience in planning and selecting sites for wastewater treatment plants and the ability to match these sites with farmlands that can reuse it [13]. There was also a study for biological water quality assessment of shallow urban streams based on abundance and diversity of benthic macroinvertebrate communities the case of Nima Creek in Ghana.[14]. It is also necessary to know the environmental state and water quality by phytoplankton[15].

The present study aims to:

1. Managment water resources between supply and demand of the Euphrates River water in Anbar Province to obtain sufficient water for domestic, agricultural and industrial uses without future problems.

2. Recommendation for future sustainable management of water in the region to be considered by water resources managers and stakeholders.

\section{Description of the Study Area}

\subsection{Al-Anbar Province}

Anbar Province is considered one of the largest provinces in Iraq in terms of area. Its area is about $(137,808$ $\mathrm{km}^{2}$ ), which constitutes (31.7\%) of the total area of Iraq, which is $\left(435052 \mathrm{~km}^{2}\right)$. It is located in the western part of Iraq within the western plateau that occupies about (55\%) of the area of Iraq [16]. Its total population is about (one million and 660 thousand people), according to the census of January 12, 2014 [1]. It lies between longitudes $\left(40^{\circ}, 28^{\prime}, 12^{\prime \prime}\right)$ - $\left(41^{\circ}, 25^{\prime}, 48^{\prime \prime}\right)$ East and latitude (34 $\left., 24^{\prime}, 54^{\prime \prime}\right)$ - (34ํ, 11', 6") from North [17].

Administrative divisions include: Al-Qaim district, Rawa district, Anah district, Haditha district, Hit district, Al-Rutba district, Al-Ramadi district and Al-Fallujah district.

Most of these districts are located near the banks of the Euphrates because these cities depend mainly on the waters of the Euphrates for all uses, which makes this river the main artery in feeding all the provinces.

\subsection{The Euphrates River}

The Euphrates is one of the international rivers that passes in three countries: Turkey, Syria, and then Iraq as it enters the lands of the study area at the village (Western Husaybah) located within the district of Al-Qaim[18]. The vital interests of the three countries are directly related to the Euphrates, as political, economic, social, and legal factors, especially since each country has the right to obtain a fair share of water and it must be respected by the riparian states by international laws.

The Euphrates River runs for a distance of approximately $(545 \mathrm{~km})$ within the study area which constitutes (43\%) of the total length of the Euphrates River inside Iraq and (17\%) of the total length of the river from its source in Turkey even downstream in Iraq, which makes the total length $(2940 \mathrm{~km})$, and its length inside the Iraqi border $(1167 \mathrm{~km})$ [1]. The annual water supply of the Euphrates River fluctuates in its quantities from one year to another due to the different factors affecting the upstream water supply area, as well as the geological structure of the basin, topography, nature of the soil, climate, natural vegetation, area of the basin and its characteristics which all have important impact in determining the amount of running water in the river [19][18][20]. In recent years, the discharge of the Euphrates River has started to decrease gradually because the State of Turkey has activated the Gap project, which consists of approximately 22 dams, in addition to climate change [21]. In figure (1) shows the targeted study area in Anbar province. 


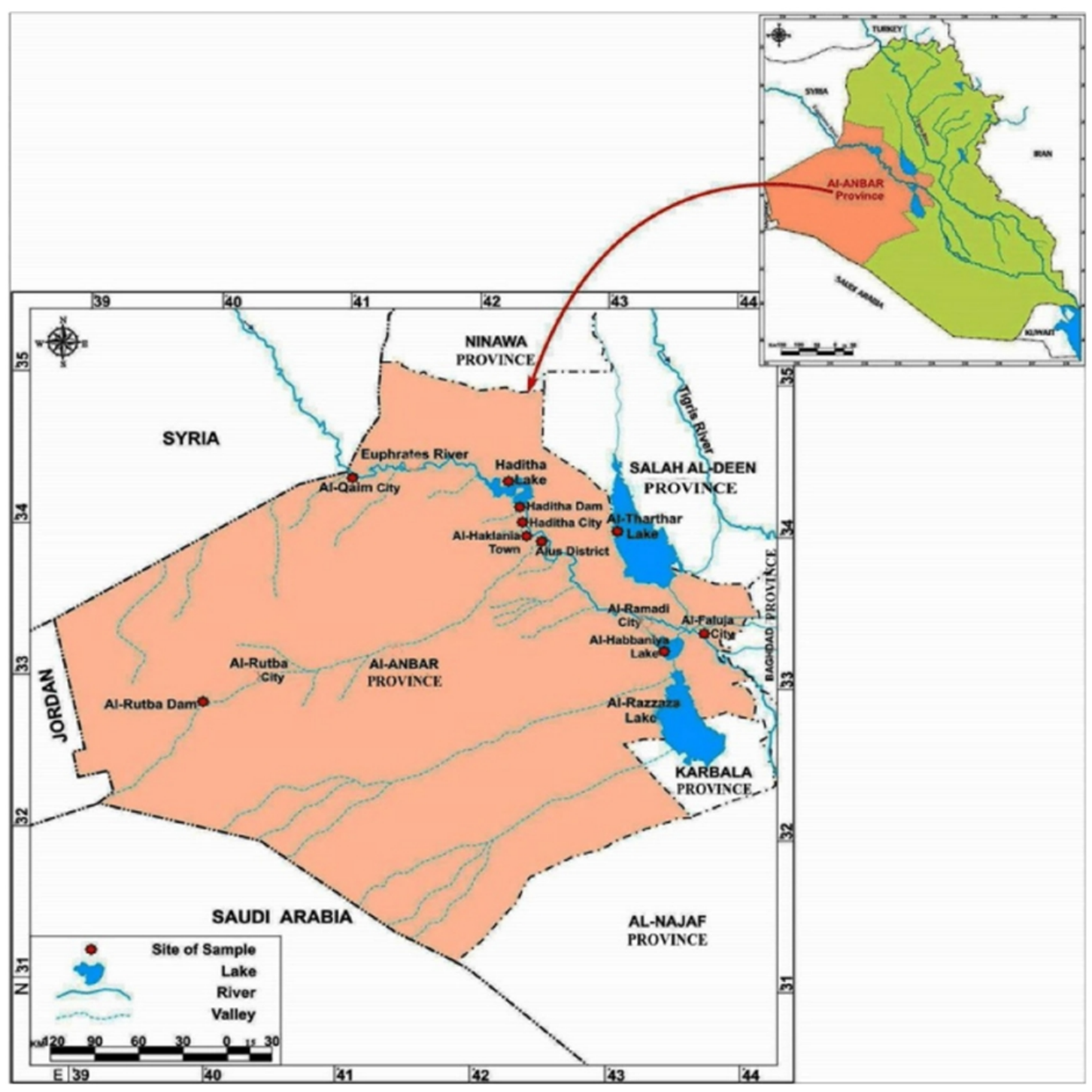

Figure 1. Location of the study area

\section{Theory and Methods}

The different stages of surface water resource management in this study are: estimation of the amount of water received for each year in the Euphrates River, estimating the amount of water needed for the domestic, the agricultural, and the industrial sector. The study will take the future water demand for Anbar Province for the domestic sector into account using the WEAP model for the reference scenario and the taxation scenario for domestic water use. The model is built for the purpose of planning and managing water resources in the region in accordance with the development plan (2040) which is prepared by the competent authorities. Two scenarios based on the data of the base year are used.

\subsection{Experimental Design}

The WEAP (Water Assessment and Planning) program was implemented to predict future water demand across three regions along the Euphrates River, namely; Ramadi, Fallujah, and Gharbia. In WEAP, modeling the typical scenario consists of three steps. At the outset, a Current Accounts year was specified to represent the base year of the model; then a Reference Scenario was determined from the Current Accounts to simulate the probable evolution of the system when no intervention occurs. Subsequently, "what-if" scenarios were followed to modify the "Reference Scenario" and gauge the possible resulting effects of the changes projected to occur in policies and/or technologies. Data ranging over the period 2008-2019 constituted the basic input in modeling the current accounts. To distribute the presumed resources, a number of possibilities were tested by developing several scenarios where future water demands are projected.

\subsection{Introduction to the WEAP Model}

This model was under development and use in the 
water-planning discipline for a long time [12]. The Aral Sea was the first region to be studied by the WEAP model. That first version of WEAP, however, was quite limited. Among the many shortcomings of the first version was the assumption of river independence in the allocation scheme, and prioritizing demand on upstream over the downstream sites. The new WEAP21 circumvents those shortcomings in addition to introducing further major advances including a modern Graphic User Interface (GUI), a modern more robust and efficient solution algorithm for solving the water allocation problem, and the integration of hydrologic sub-modules that includes a conceptual rainfall runoff, a sedimentary groundwater model, and a stream water quality model [22]. The WEAP model which was initiated, developed, and being maintained by the Stockholm Environment Institute (SEI), operates at a default time step of a month assuming the basic principles of water balance accounting. Different supply sources (e.g. rivers, groundwater, and reservoirs), withdrawals, water demands, and ecologies were taken into account [23].

\subsection{The WEAP Algorithm}

The demand presented by some demand sites (DS) is computed as the sum of the corresponding demands of all the bottom-level branches $(\mathrm{Br})$ of that particular site.

\section{AnnualDemand $_{\mathrm{DS}}=$ \\ $\sum_{B r}($ TotalActivityLevelBr $\times$ WaterUseRateBr $)$}

of the inflows of the corresponding transmission links. The inflow entering the demand site from a supply source $(S r c)$ is defined as the outflow corresponding to those transmission links joining them.

$$
\text { DemandSiteInflow }=\sum_{\text {Src }} \text { TransLinkOutflowSrc, Ds }
$$

\subsection{Description and Input Data}

This study was conducted in a WEAP model from the year 2008 to the year 2040. The year 2008 was considered the year of the current accounts in the model. We used the base year for a one-year period because data is not available. Data on the annul inflow of the Euphrates River water entering Anbar Province were obtained at Al-Qaim City Station for several years as shown in Figure 2. The annul import amount of the Euphrates River for the last years has begun to decline gradually from the first years and therefore may not meet the requirements of water demand at present for the domestic, industrial and agricultural sectors. The share of Anbar Province in the total amount of water entering Iraq is $17 \%$. The present researchers made a chart showing the flow of the Euphrates River entering Iraq from Al-Qaim Station from the year 1995 to the year 2019. The figure 2 also shows the changes in the inflow of the Euphrates River every four years and more or less than 4 years can be taken here just to show the rate of decrease in water flow.

The quantity delivered to a demand site (DS) is the sum

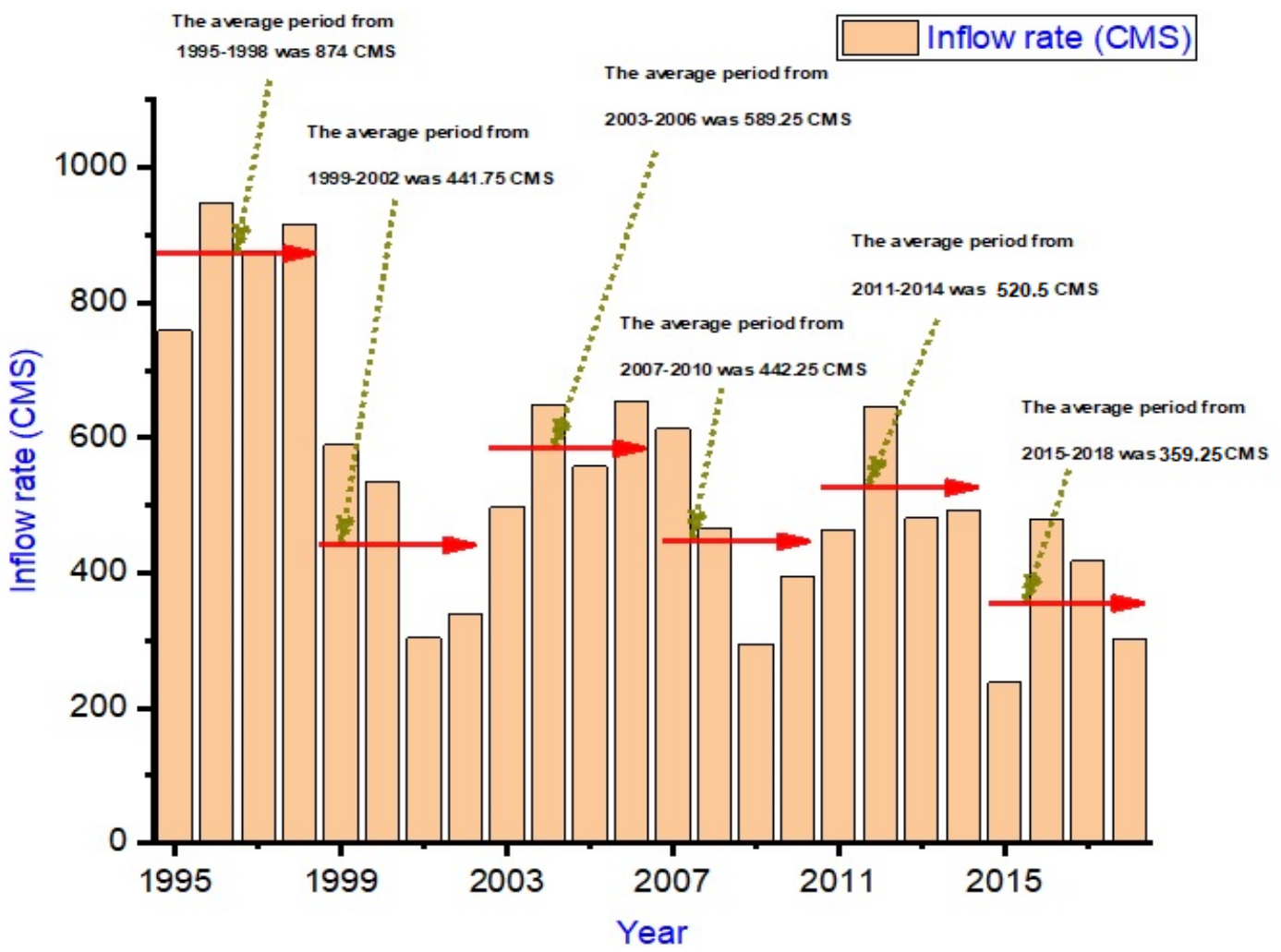

Figure 2. The flow of the Euphrates and the changes in the flow levels of the river every 4 years 


\subsection{Water Demand of the Population}

The population of the Province depends primarily on the Euphrates for all its domestic, industrial and agricultural uses, as the demand for water increases with the increase in the population of the Province, as well as the absence of indicative programs for ways to use water, [24].

The amount of water per capita per day in the Province is 500 liters. They include actual per capita consumption (300 liters), losses in dilapidated transport pipelines, environmental uses, gardens, parks, washing, et. That is 182.5 cubic meters per year including drinking water, washing, sanitation, etc. Those figures were adopted in the present study. Since the base year is 2008, the last population census was obtained in the year 2007 according to which 1485985 persons inhabited the area. Since we have the 2007 census data, and the approximate population growth rate for the province is $3 \%$ [25], according to the population percentage for 2008, which will be 1530564 person approved in the WEAP model. The population growth for the rest of the years 2009-2040 was taken into consideration as $3 \%$ which the WEAP model applied. The model also requires entering the actual consumption of the required water amount, which is $15 \%$ of the consumptive losses for the demand site-water that is lost to evaporation or output to the sewage network. Priority will be to meet the demand for domestic. The percentage of the population of the three branches of the districts was entered from the percentage of the total population (urban and rural) in the model, respectively, in Gharbia, Ramadi, and Fallujah (27.98\%, 36.37\% and 35.69\%).

\subsection{Analysis of Scenarios and Description of Future Scenarios}

\subsubsection{Reference scenario}

The reference scenario is years from 2008 to 2019 and future water demand predicted from 2020 to 2040in Anbar Province. The calculations were based on the data for the base year 2008 for the three sectors (domestic, industrial and agricultural), but the variable will be the average annual flow of the river that determines whether there is unmet demand for the sectors above and thus we can develop scenarios to solve problems that occur in the future.

In the present study, annual flows of the river were obtained from 2008-2019 only. This data set was not sufficient for the purposes of the present study up to the year 2040. To get results and to know whether the demand will be met in the future. Therefore, the time series method was used to predict the amounts of the annual flow of the river in the future from year 2021-2040 as shown in the Table (1).

Table 1. The annual flow rate of the Euphrates River in Al-Qaim Station in Al-Anbar Province

\begin{tabular}{ccc}
\hline Year & $\begin{array}{c}\text { Total annual flow } \\
\text { rate (CMS) }\end{array}$ & $\begin{array}{c}\text { Anbar province } \\
\text { share }(17 \%)\end{array}$ \\
2008 & 466 & 79.22 \\
2010 & 295 & 50.15 \\
2011 & 395 & 67.15 \\
2012 & 463 & 78.71 \\
2013 & 646 & 109.82 \\
2014 & 481 & 81.77 \\
2015 & 492 & 83.64 \\
2016 & 237 & 40.29 \\
2017 & 480 & 81.6 \\
2018 & 417 & 70.89 \\
2019 & 303 & 51.51 \\
& 454 & 77.30 \\
\hline
\end{tabular}

The average annual flows of the Euphrates in the future were calculated using the time-series methodology (Box-Jenkins) [24]. This enabled predicting future water demand for the region. The Anbar Province's share of the annual flow of the Euphrates River was entered into the WEAP model from 2008-2040 as shown in Figure (3). 


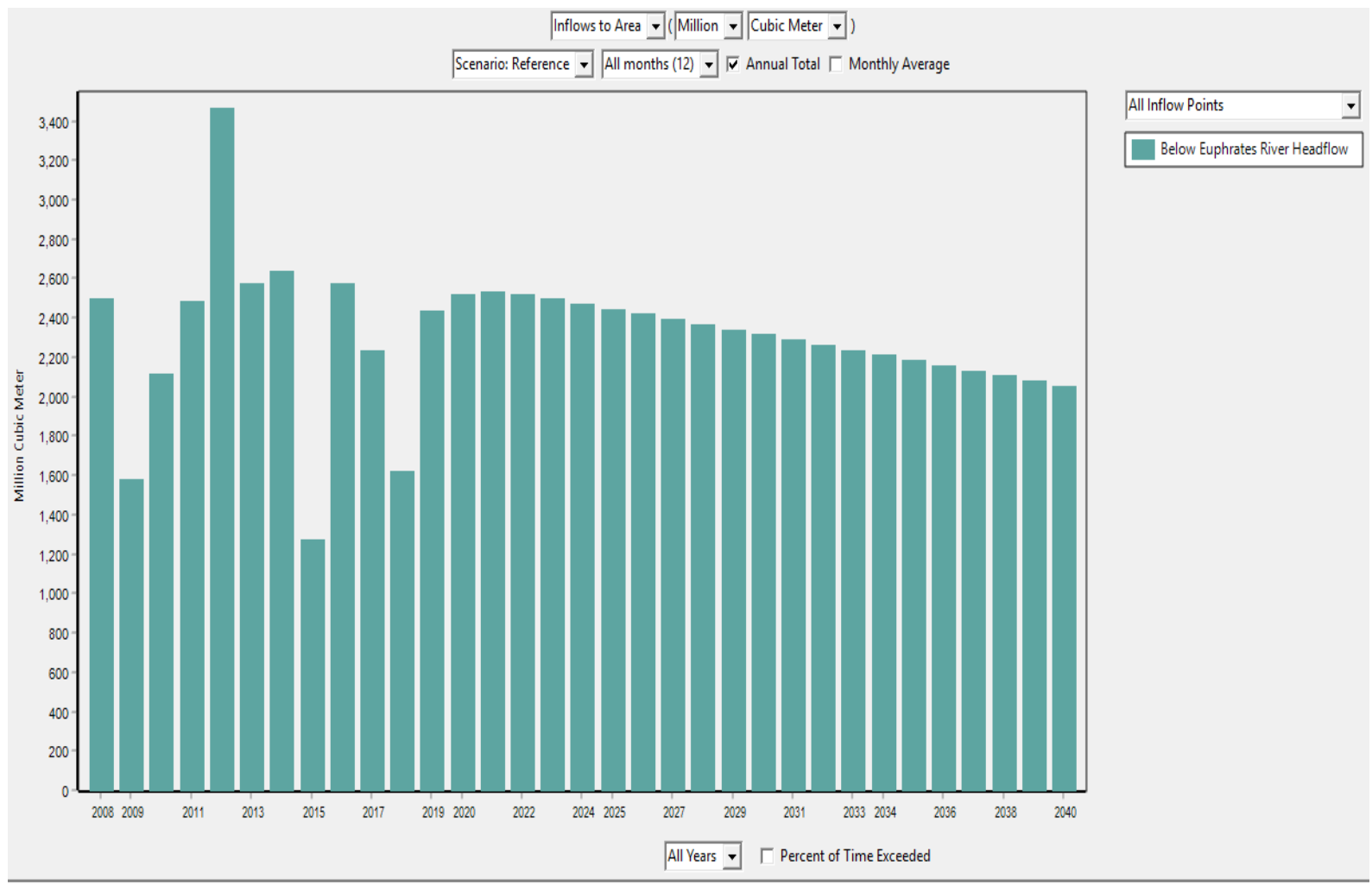

Figure 3. Anbar Province share of the annual flow of the Euphrates River from the year 2008-2040

\subsubsection{Tax on water}

In this scenario, financial sums are imposed on the water in the domestic sector in Anbar Province, as this tax is to reduce the amount of water consumed per capita by $25 \%$ of the total water per day. A Provinces study was conducted in the central Euphrates region including five provinces: Karbala, Najaf, Babil, Qadisiya and Muthanna and it was found that imposing this taxing reduced the water used by about 25\%[26].

In the present work, the requirement for water per person per day was taken as 500 liters, so after this scenario is performed the water requirement per person per day will decrease from 500 to 375 liters. That is, from 182.50 to 136.87 cubic meters per year. The value used in the WEAP model was from 2009-2040, thus we can know the amount of water that will be available to us from this economic hypothesis, taking into consideration the financial value per liter imposed.

\section{Results and Discussion}

In the Reference scenario, the results indicate an increase in the demand for water for the domestic sector in Anbar province, due to the continuous population growth. Figure (4) shows the results of future water demand in the reference scenario for the domestic sector for all three divisions of Al-Anbar Province (Ramadi, Fallujah, and Gharbia), where the demand increases with the increase in the population. As the water demand reached the three sites in Fallujah, Gharbia, and Ramadi in 2008 (99.52, 78.16, and 101.59) million cubic meters, respectively while in 2040 the water demand would be (256.28, 201.26, and 261.61) million cubic meters, as this increase is indicated by the increase in population.

As for the water tax scenario, the results of this scenario indicate a clear reduction in water consumption for the province that differs from the reference scenario after imposing taxes on the residents of the region, which helps this rationalization to provide quantities of water that can be used in other branches. Figure (5), shows the results of the quantity of water demand in the domestic sector for the three locations in the future (Ramadi, Fallujah, and Gharbia) for a water tax scenario. 


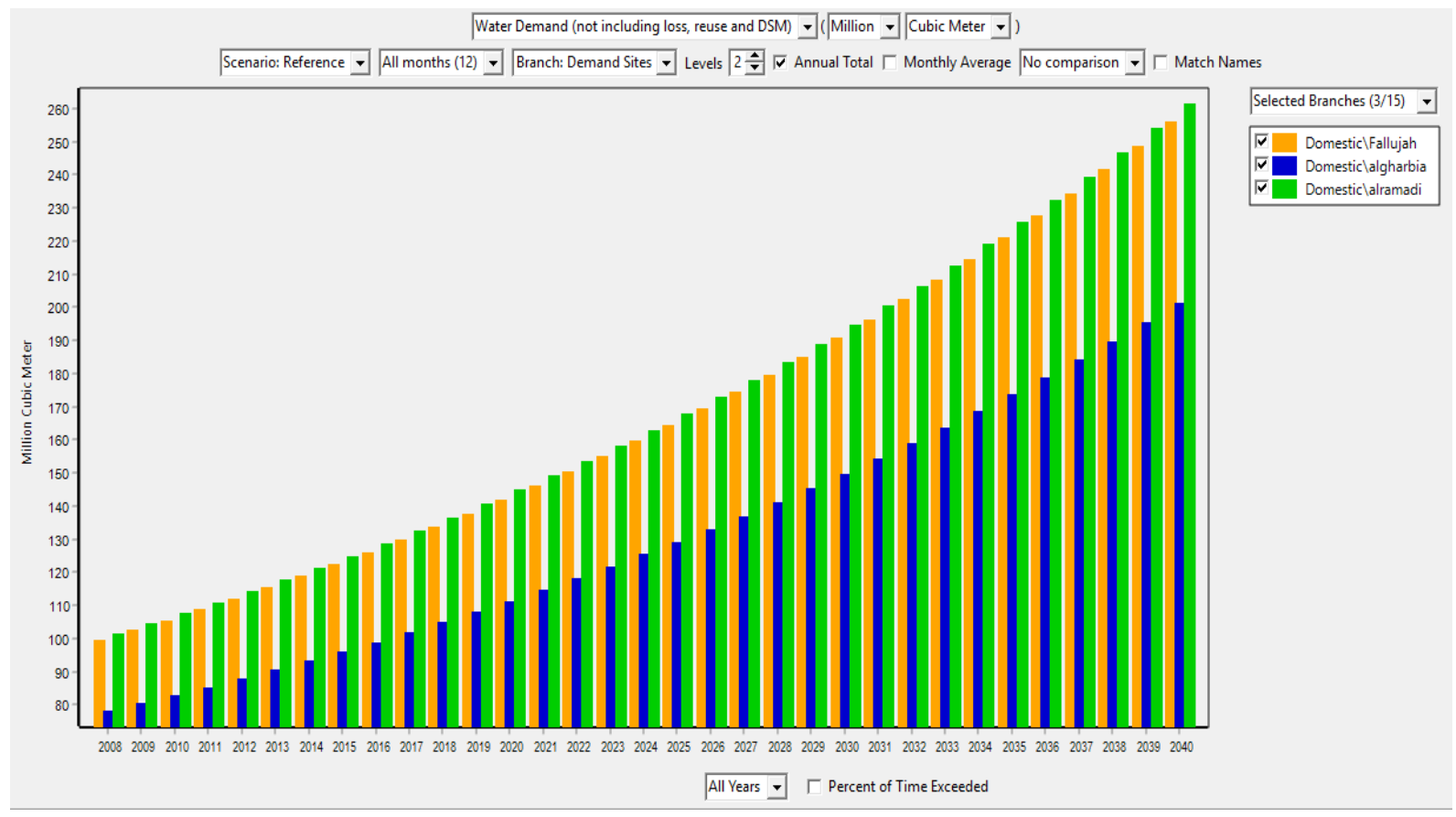

Figure 4. Water demand for the domestic sector for the three locations in the future in study period of 2008-2040

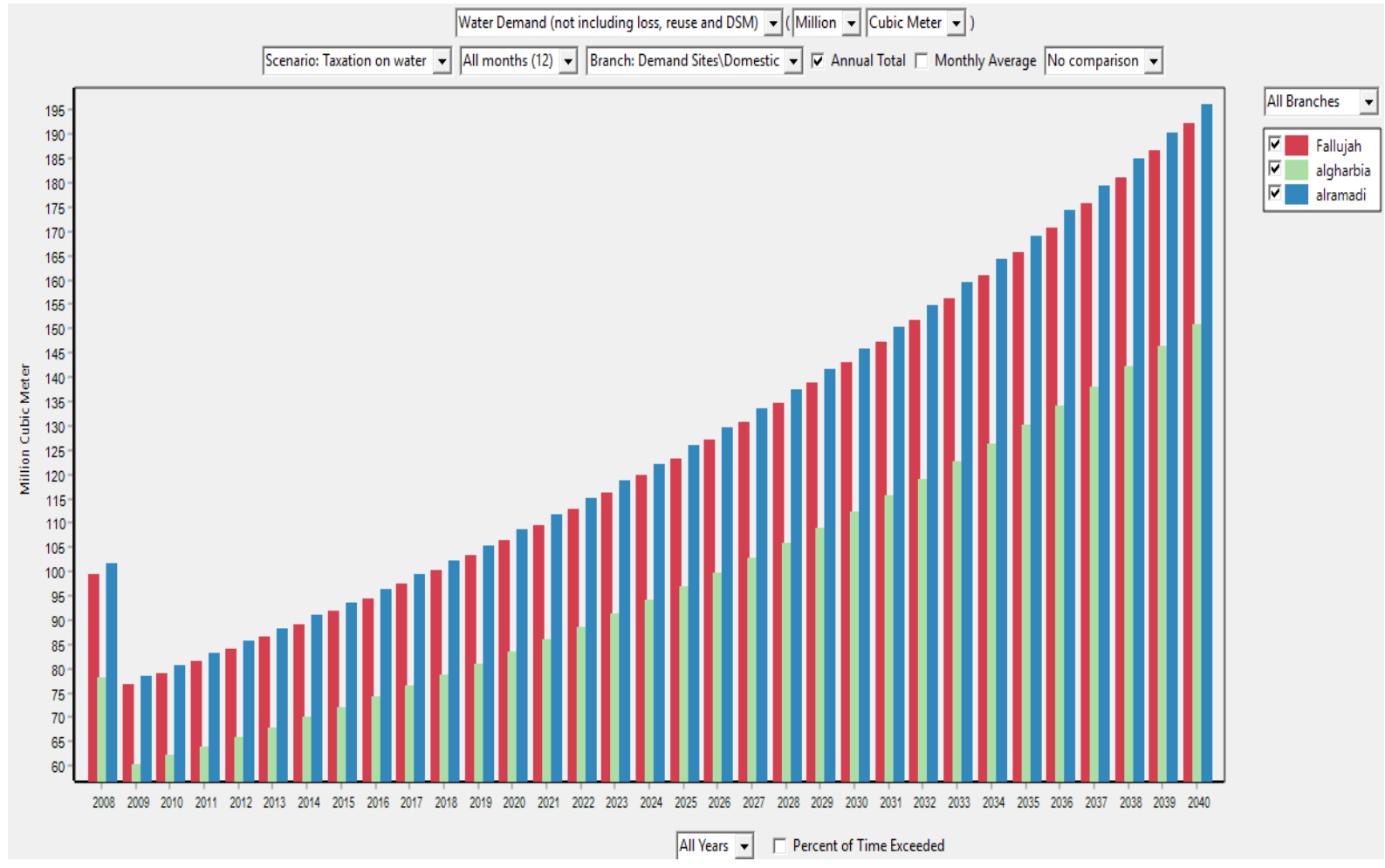

Figure 5. Water demand in the domestic sector for a water tax scenario 


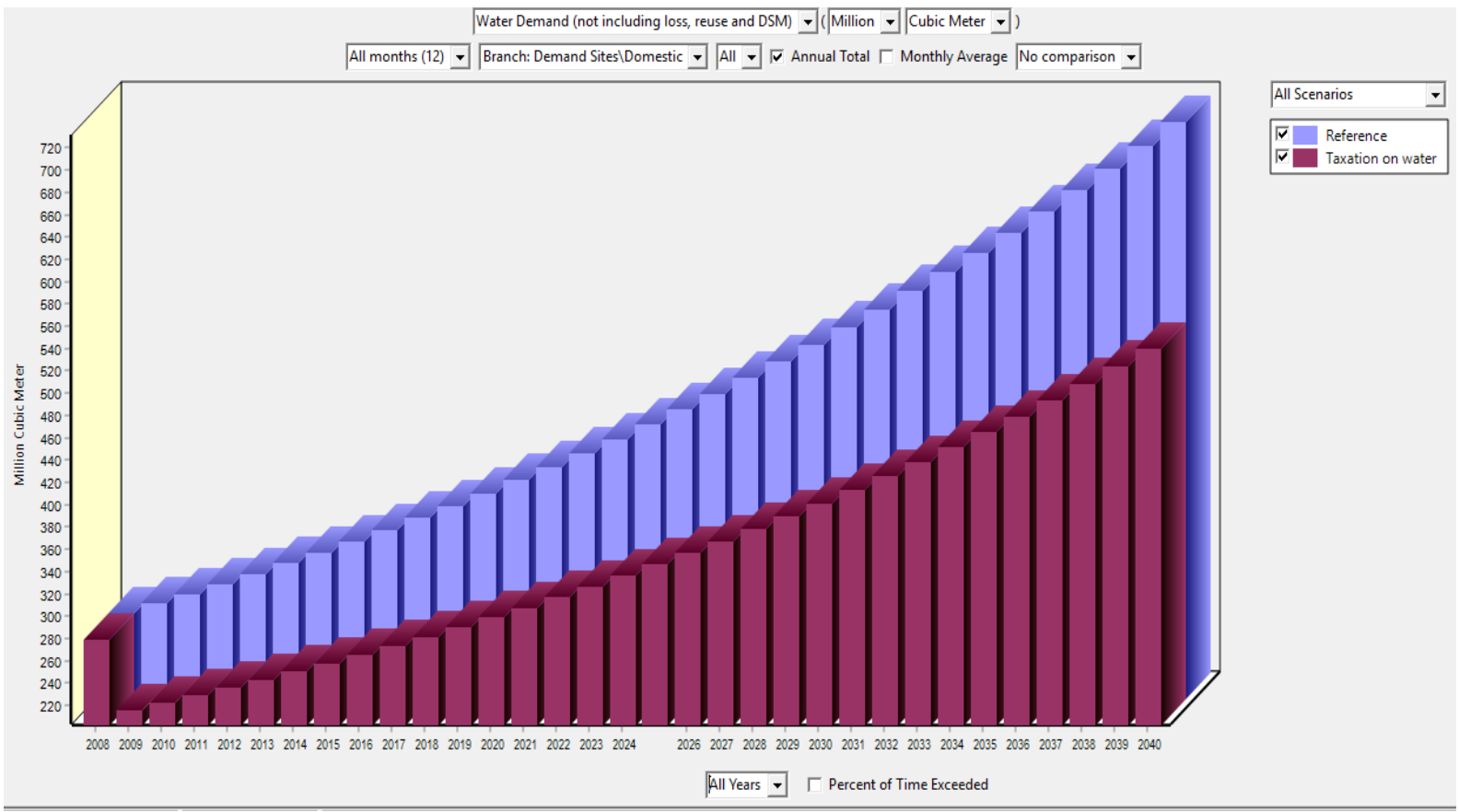

Figure 6. Comparison of water demand between the reference scenario and the tax scenario in the domestic sector from 2008-2040

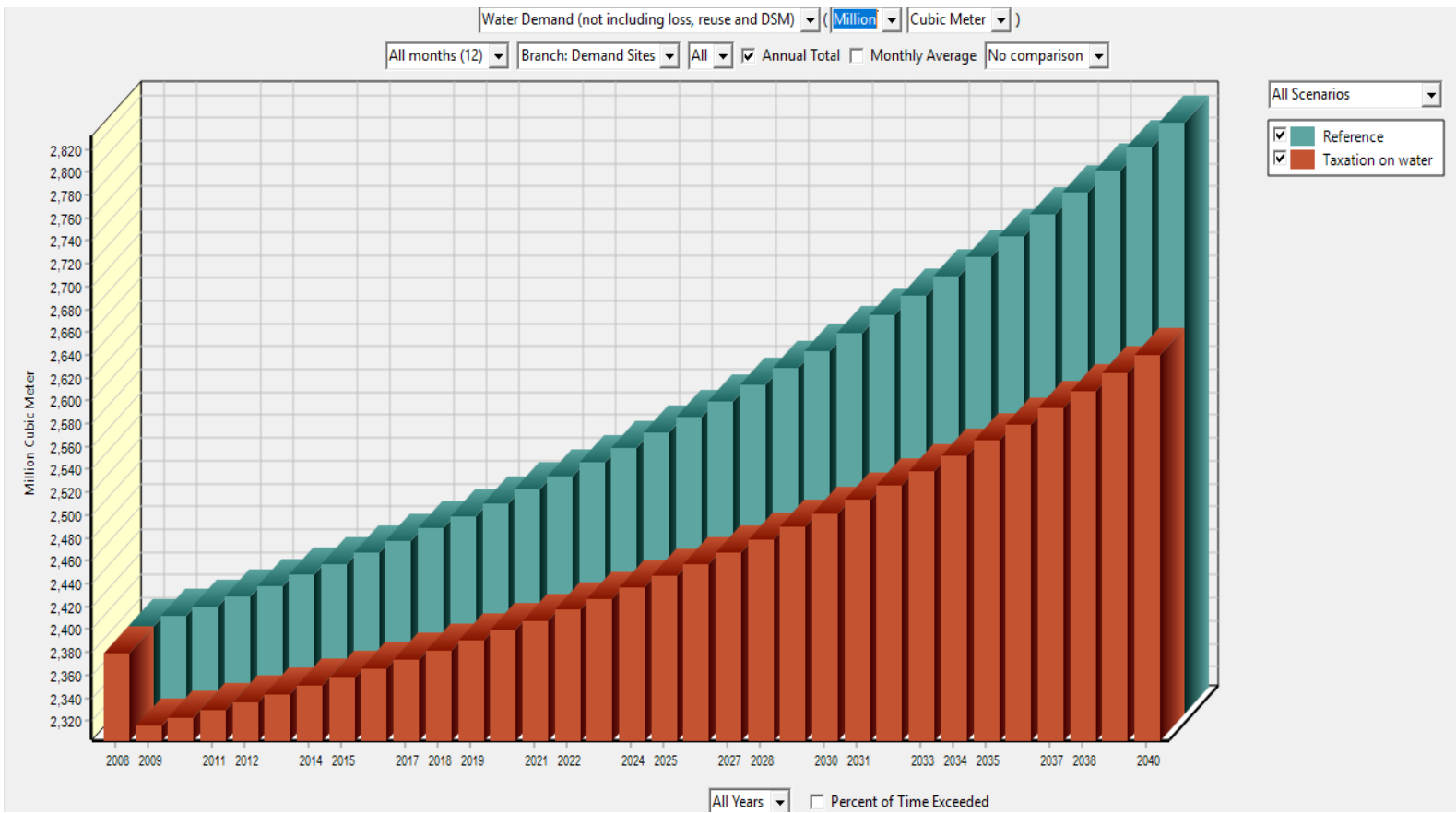

Figure 7. Results of water demand in Anbar Province between two scenarios 2008-2040

Figure (6) below shows a comparison of the results for water demand between the reference scenario and the tax scenario in the domestic sector from 2008-2040, where the figure shows the large amount of water involved in this scenario, which will lead to a reduction in a large amount of wasted water and benefit from it in the future. The results, also, show the difference in the amount of water demand between the two scenarios. A large amount of water consumed each year was saved to the domestic sector in the tax scenario, which reduces the water deficit, as the demand for water in the reference scenario in 2040 reached 719.14 million cubic meters, while in the tax scenario, 539.34 million cubic meters were in demand, which will save 179.8 million cubic meters that can be used in other ways.

As for the total water demand for the domestic, industrial and agricultural sectors, the results of the scenarios for water demand and unmet water demand for the three sectors were analyzed and discussed. Figures (7) shows the results of water demand and unmet demand for 
water in Anbar governorate from 2008 to 2040. The figure shows the percentage of variation between water demand quantities and unsatisfactory quantities from one scenario to another, which allows to develop a complete study and water management in the future.
Table (2) shows the results of water demand among all the scenarios. Using those results, it is possible to know the most suitable scenarios that can be used to save water, and thus a future study can be developed to address water scarcity.

Table 2. Water demand for both the reference scenario, water taxes and the use of modern irrigation methods.

\begin{tabular}{|c|c|c|}
\hline Year & Scenario Reference (Million cubic meters) & Scenario Taxation on water (Million cubic meters) \\
\hline 2008 & 2379.47 & 2379.47 \\
\hline 2009 & 2387.85 & 2315.93 \\
\hline 2010 & 2396.48 & 2322.4 \\
\hline 2011 & 2405.37 & 2329.07 \\
\hline 2012 & 2414.52 & 2335.93 \\
\hline 2013 & 2423.95 & 2343 \\
\hline 2014 & 2433.66 & 2350.29 \\
\hline 2015 & 2443.67 & 2357.79 \\
\hline 2016 & 2453.97 & 2365.52 \\
\hline 2017 & 2464.59 & 2373.48 \\
\hline 2018 & 2475.52 & 2381.68 \\
\hline 2019 & 2486.78 & 2390.12 \\
\hline 2020 & 2498.37 & 2398.82 \\
\hline 2021 & 2510.32 & 2407.78 \\
\hline 2022 & 2522.62 & 2417.01 \\
\hline 2023 & 2535.3 & 2426.51 \\
\hline 2024 & 2548.35 & 2436.3 \\
\hline 2025 & 2561.79 & 2446.38 \\
\hline 2026 & 2575.64 & 2456.77 \\
\hline 2027 & 2589.9 & 2467.46 \\
\hline 2028 & 2604.6 & 2478.48 \\
\hline 2029 & 2619.73 & 2489.83 \\
\hline 2030 & 2635.31 & 2501.52 \\
\hline 2031 & 2651.37 & 2513.56 \\
\hline 2032 & 2667.9 & 2525.96 \\
\hline 2033 & 2684.93 & 2538.73 \\
\hline 2034 & 2702.47 & 2551.89 \\
\hline 2035 & 2720.54 & 2565.44 \\
\hline 2036 & 2739.15 & 2579.4 \\
\hline 2037 & 2758.32 & 2593.77 \\
\hline 2038 & 2778.07 & 2608.58 \\
\hline 2039 & 2798.4 & 2623.83 \\
\hline 2040 & 2819.35 & 2639.54 \\
\hline
\end{tabular}




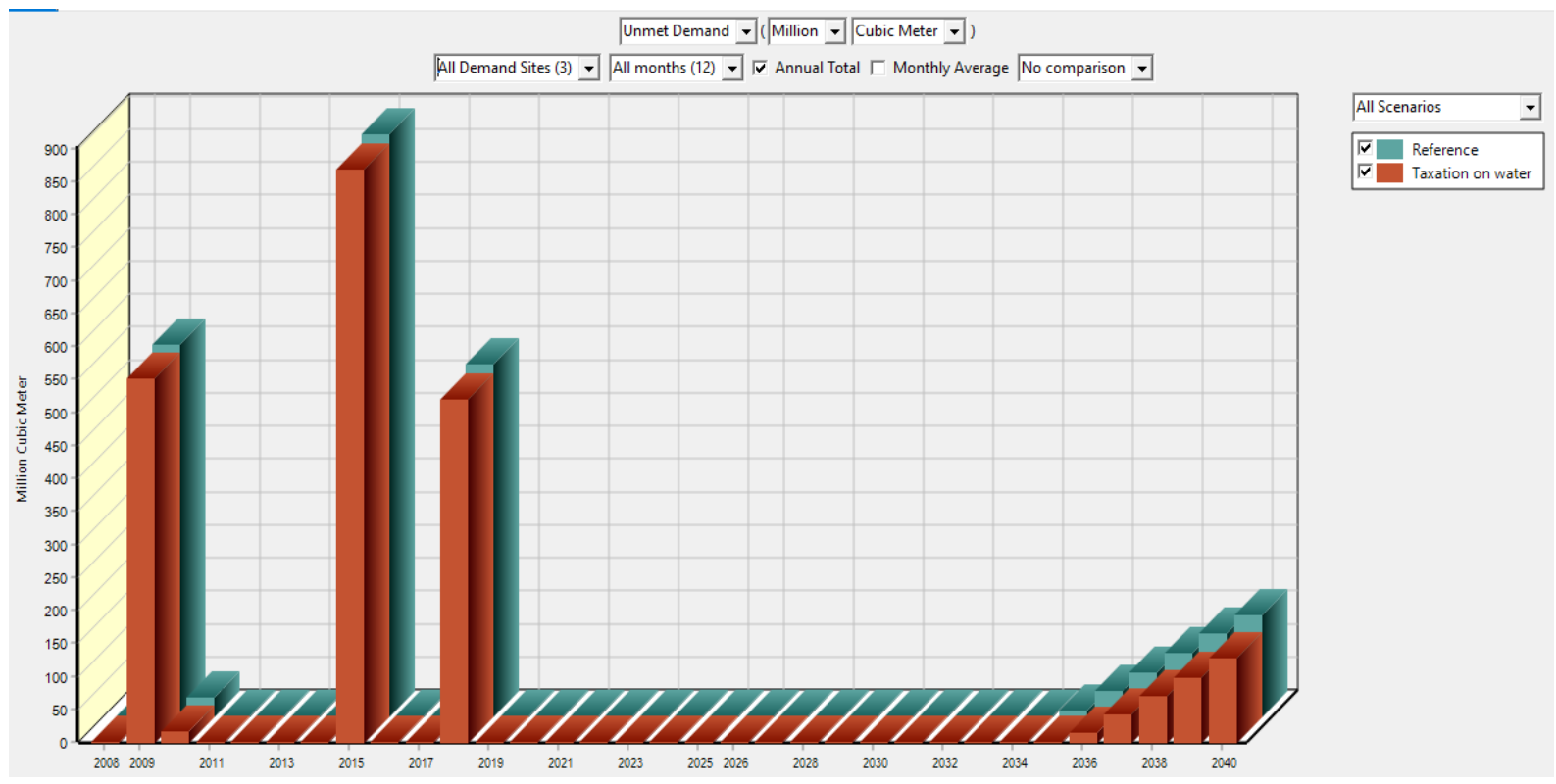

Figure 8. Unmet demand for water in Anbar Province between two scenarios

Figure (8), below, shows the results of the unmet demand for water in Anbar Province in three scenarios during the period 2008-2040. These results enable knowing the amount of the deficit in water that cannot be provided to the three sectors (domestic, industrial and agricultural) if sufficient quantities of the Euphrates water are not available and to find suitable solutions and alternatives in the future.

Table (3) shows the results of unmet water demand for two scenarios. The amount of unsaturated water depends on the annual flow of the Euphrates. The results indicate that the scenario of imposing taxes on water will reduce unmet demand in 2040 by about 27 million cubic meters.

Table 3. The unmet demand for water for both the reference scenario and taxes on water

\begin{tabular}{ccc}
\hline Year & $\begin{array}{c}\text { Scenario Reference } \\
\text { (Million cubic meters) }\end{array}$ & $\begin{array}{c}\text { Scenario Taxation on water } \\
\text { (Million cubic meters) }\end{array}$ \\
\hline 2009 & 561.83 & 551.04 \\
2010 & 27.01 & 15.89 \\
2015 & 881.14 & 868.26 \\
2018 & 532.08 & 518.01 \\
2035 & 8.13 & 0 \\
2036 & 37.09 & 13.13 \\
2037 & 66.14 & 41.46 \\
2038 & 94.97 & 69.54 \\
2039 & 124.19 & 98.01 \\
2040 & 153.19 & 126.22 \\
\hline
\end{tabular}

Based on the provided charts, we will discuss the future results at the end of each five years $(2025,2030,2035$,
2040).

In the reference scenario, the water demand for the three domestic, industrial, and agricultural sectors was 2561.79, 2635.51, 2720.54, 2819.35 million cubic meters for the years 2025, 2030, 2035, 2040, respectively.

The unmet demand was $0,0,8.13,153.19$ million cubic meters. While in the water tax scenario, the water demand for the three domestic, industrial and agricultural sectors was 2446.38, 2501.52, 2565.44, 2639.54 million cubic meters for the years 2025, 2030, 2035, 2040, respectively.

Unmet demand was 0, 0, 0, 126.22 million cubic meters.

\section{Conclusions}

The Water Assessment Model (WEAP) was used successfully to estimate the amount of water demand and unmet demand in the future for the cities of Anbar Province in Iraq. The model required broad data for the study area, and these data sets were classified into field data, past research data, as well as government departments' data. Based on the results obtained from this study, the following conclusions can be drawn:

1. The results of the study indicate that there is a decrease in the flow rate of the Euphrates River in the coming years and thus the demand may do not meet for water and the occurrence of a deficit in the amount of water. As the unmet demand in 2040 was 153.19 million cubic meters, which requires developing solutions for water management in the future to cover the demand for Water in the domestic, industrial and agricultural sectors.

2. In the reference scenario, the results of the water demand for the three household, industrial and agricultural sectors for the year 2040 were 2819.35 
million cubic meters and the unmet water demand was 153.19 million cubic meters.

3. In the water tax scenario, the results of water demand for the three household, industrial and agricultural sectors for the year 2040 were 2,639.54 million cubic meters, and the unmet water demand was 126.22 million cubic meters, which is less than the reference scenario.

\section{Acknowledgements}

Acknowledgment the researcher to the Faculty of Engineering, Al_Azhar University and to the Department of Graduate Studies in the College of Engineering.

\section{REFERENCES}

[1] Hamad M, “The Integrated Management for Water Resources in Al-Anbar Governorate,” no. 16956, pp. 1-172, 2015.

[2] Jameel. B and Jawad. F, "The most famous water in iraq and integrated management requirements for the development of water resources,” no. 27, 2017.

[3] Rogers P. and and Lydon P., "Water in the Arab World, Massachusetts," Harvard Univ. Press. USA., 1994.

[4] J., Barr .S., Grego.E., Hassan.M., Niasse.W., Rast J..Talafré, "Regional challenges, global impacts, in Managing Water under Uncertainty and Risk," UN World Water Dev. Rep. 4 chapter 7, 2012.

[5] Chenoweth J., "Impact of climate change on the water resources of the eastern Mediterranean and Middle East region: modeled 21st century changes and implications.," Water Resour Res 47, 2011.

[6] I. Issa, "Expected future of water resources within Tigris-Euphrates Rivers Basin, Iraq," J Water Resour Prot 6, pp. 421-432, 2014.

[7] Yaseen ZM and S. S. Awadh SM, Sharafati A, "Complementary data-intelligence model for river flow simulation.,” J Hydrol 567, pp. 180-190, 2018.

[8] Tao H and R. M. et al Bobaker AM, "Determination of biochemical oxygen demand and dissolved oxygen for semi-arid river environment: application of soft computing models,” Env. Sci Pollut Res, 2018.

[9] Z. M. Mounir, C. M. Ma, and I. Amadou, “Application of water evaluation and planning (WEAP): A model to assess future water demands in the Niger River (in Niger Republic)," Mod. Appl. Sci., vol. 5, no. 1, pp. 38-49, 2011, doi: 10.5539/mas.v5n1p38.

[10]L. Yang et al., "Water evaluation and planning (Weap) model application for exploring the water deficit at catchment level in beijing,” Desalin. Water Treat., vol. 118, pp. 12-25, 2018, doi: 10.5004/dwt.2018.22332.
[11] S. M. Yadav and S. Saxena, "Application of Water Evaluation and Planning Model to Assess Future Water Demands of Surat City,” no. March, pp. 557-563, 2016.

[12] P. Raskina, E. Hansen, Z. Zhu, and D. Stavisky, "Simulation of water supply and demand in the aral sea region," Water Int., vol. 17, no. 2, pp. 55-67, 1992, doi: $10.1080 / 02508069208686127$.

[13] E. Yaqob, R. Al-Sa`ed, G. Sorial, and M. Suidan, "Simulation of trans boundary wastewater resource management scenarios in the Wadi Zomer watershed, using a WEAP model,” Int. J. Basic Appl. Sci., vol. 4, no. 1, pp. 2735, 2014, doi: 10.14419/ijbas.v4i1.3802.

[14] L. A. Nuamah, J. Huang, and H. R. Dankwa, "Biological Water Quality Assessment of Shallow Urban Streams Based on Abundance and Diversity of Benthic Macroinvertebrate Communities: The Case of Nima Creek in Ghana,” Environment and Ecology Research, vol. 6, no. 2, pp. 93-101, 2018, doi: 10.13189/eer.2018.060201.

[15] S. Barinova and E. Krupa, "Bioindication of Ecological State and Water Quality by Phytoplankton in the Shardara Reservoir, Kazakhstan,” Environment and Ecology Research, vol. 5, no. 2, pp. 73-92, 2017, doi: 10.13189/eer.2017.050201.

[16] S. O. Sulaiman, A. H. Kamel, K. N. Sayl, and M. Y. Alfadhel, "Water resources management and sustainability over the Western desert of Iraq,” Environ. Earth Sci., vol. 78, no. 16, pp. 1-15, 2019, doi: 10.1007/s12665-019-8510-y.

[17] A. S. Mustafa, S. O. Sulaiman, and O. M. Hussein, "Application of swat model for sediment loads from valleys transmitted to Haditha reservoir,” J. Eng., vol. 22, no. 1, pp. 184-197, 2016.

[18] A. B. A. Najm, I. M. Abdulhameed, and S. O. Sulaiman, "Water Requirements of Crops under Various Kc Coefficient Approaches by Using Water Evaluation and Planning (WEAP),” Int. J. Des. Nat. Ecodynamics, vol. 15, no. 5, pp. 739-748, 2020, doi: 10.18280/ijdne.150516.

[19] L. M. M. Salih and S. A. A. Al-Dulaimi, "Hydraulic Condition of Euphrates in Iraq and its Effects on Irrigation Projects," Literature, vol. 2, no. 131, pp. 283-310, 2019.

[20] S. O. Sulaiman, G. Al-Dulaimi, and H. Al Thamiry, "Natural rivers longitudinal dispersion coefficient simulation using hybrid soft computing model," Proc. - Int. Conf. Dev. eSystems Eng. DeSE, vol. 2018-Septe, no. Ldc, pp. 280-283, 2019, doi: 10.1109/DeSE.2018.00056.

[21] N. Al-Ansari, N. Adamo, V. K. Sissakian, S. Knutsson, and J. Laue, "Water Resources of the Euphrates River Catchment," J. Earth Sci. Geotech. Eng., vol. 8, no. 3, pp. 1792-9660, 2018.

[22] C. Rosenzweig et al., "Water resources for agriculture in a changing climate: International case studies," Glob. Environ. Chang., vol. 14, no. 4, pp. 345-360, 2004, doi: 10.1016/j.gloenvcha.2004.09.003.

[23] P. Raskin, J. Sieber, and A. Huber-Lee, "Water Evaluation and Planning System: User guide for WEAP 21,” Tellus Institute, Boston, MA, vol. 15, 2001. 
[24] Ahmed jassam mukhlif, "Continental in The climate Anbar of Governorate Dr.Ahmed,” Anbar Univ. Humanit., vol. 1, 2019.

[25] National Commite on Population Policy, “The first national report on the state of the population in the context of the recommendations of the Cairo Conference on Population and the Millennium Development Goals,” pp. 1-81, 2011.

[26] K. Riyadh, “Urban uses of water in Iraqi cities,” Plan. Dev., vol. 34, pp. 241-265, 2016. 